\title{
The Effectiveness of Aromatherapy and Music Therapy to Reduce Pain during Stage-1 of Birth Delivery: A Meta-Analysis
}

\author{
Uswatun Hasanah'), Bhisma Murti'), Hanung Prasetya3) \\ 1)Masters Program in Public Health, Universitas Sebelas Maret \\ 2)Faculty of Medicine, Universitas Sebelas Maret
}

\section{ABSTRACT}

Background: Labor pain is an uncomfortable feeling during the labor process, which causes a reduction in uterine contractions, uteroplacental circulation, blood flow, and oxygen to the uterus, and causes uterine ischemia, which makes the pain impulses increase. Aromatherapy and music therapy are non-pharmacological pain management that can be given to postpartum mothers during labor that helps reduce pain. In addition, they can provide a calming sensation for the self and the brain and the stress they feel. This study aimed to analyze the effectiveness of aromatherapy and music therapy in reducing labor pain in the first stage of labor.

Subjects and Method: This was a meta-analysis and systematic study. The articles used were obtained from ProQuest, Science Direct, Google Scholar, and Springer Link. The research subjects were mothers who gave birth in the first stage. The treatment provided was aromatherapy and music therapy. The articles used were articles presented in English, in full text with a Randomized Controlled Trial design. The research problems of PICO were as follows: Population $=$ mothers giving birth, Intervention $=$ giving aromatherapy and music therapy, Comparation $=$ not being given aromatherapy and music therapy, Outcome $=$ reducing labor pain. The study analysis was carried out using RevMan $5 \cdot 3$ with Random Effect Model.

Results: Analysis of 9 articles on the effectiveness of aromatherapy on reducing labor pain showed that aromatherapy reduced labor pain $(\mathrm{SMD}=-0.85$; 95\% CI -1.14 to -0.31 ), and it was statistically significant $(\mathrm{p}<0.001)$. Analysis of 9 articles on the effectiveness of music therapy on reducing labor pain showed that music therapy reduced labor pain $(\mathrm{SMD}=-1.14 ; 95 \% \mathrm{CI}-2.18$ to -0.09$)$, and it was statistically significant $(\mathrm{p}<0.001)$.

Conclusion: Aromatherapy and music therapy effectively reduce labor pain in women giving birth in the first stage.

Keywords: aromatherapy, music therapy, labor pain

\section{Correspondence:}

Uswatun Hasanah. Masters Program in Public Health. Universitas Sebelas Maret. Jl. Ir. Sutarmi 36A, Surakarta 57126, Central Java. Email: uusuusuuso@gmail.com. Mobile: 085647582541.

\section{Cite this as:}

Hasanah U, Murti B, Prasetya H (2021). The Effectiveness of Aromatherapy and Music Therapy to Reduce Pain during Stage-1 of Birth Delivery: A Meta-Analysis. J Matern Child Health. 06(03): 295-306. https://doi.org/10.26911/thejmch.2021.06.03.04.

Journal of Maternal and Child Health is licensed under a Creative Commons

Attribution-NonCommercial-ShareAlike 4.0 International License.

\section{BACKGROUND}

Labor is the process of expulsion of the fetus that occurs at term (37-42 weeks) born spontaneously with a back of the head presentation within 18 hours without complications for both mother and fetus (Saifuddin, 2013). Labor pain is a natural process felt by mothers about to give birth, which is caused by uterine contractions, cervical dilatation, and perineal distension.
Visceral efferent nerve fibers that carry sensory and uterine impulses enter the spinal cord in the 10th, 11th, and 12th thoracic segments and the first lumbar segment (T10-l1) (Asmadi, 2012). This pain is a subjective feeling due to changes in the function of various organs of the body that also determine the smooth delivery process. The pain experienced during labor is unique and is a natural process felt by 
mothers about to give birth. Mother-to-be's reaction to the birth they face depends on their preparation and perception of the event. Various fears due to ignorance are believed to have an effect on pain during childbirth.

Pain can be influenced by several factors, including socio-cultural, pain perception, previous pain experience, gender, and others (Black \& Hawks, 2014). The pain experienced by primiparas will be more pronounced at the beginning of labor, while in multiparas, the pain will increase when labor has advanced, namely when the fetus declines, which will take place rapidly in the second stage. Labor pain can cause a sense of stress that causes the release of excessive hormones such as catecholamines and steroids. This hormone can cause smooth muscle tension and vasoconstriction of blood vessels. This can cause a decrease in uterine contractions, a decrease in utero-placental circulation, a reduction in blood flow and oxygen to the uterus, and cause uterine ischemia, making the pain impulses increase (Yanti, 2010).

Discomfort due to pain can be overcome by pain management, either to relieve pain or reduce pain to a level of comfort that the mother can accept. Pain management includes two types of interventions, namely pharmacological and non-pharmacological interventions. Non-pharmacological management, among others, can be done by giving aromatherapy and music therapy. Aromatherapy treats the body and healing diseases using essential oils (Jaelani, 2017). Aromatherapy can be used to relieve pain during childbirth because aromatherapy can provide a calming sensation for the self and the brain, as well as the stress that is felt. The smell affects parts of the brain associated with mood, emotion, memory, and learning. Aroma is captured by receptors in the nose which then provide further information to areas in the brain that control emotions and memory as well as provide information to the hypothalamus, which is a regulator of the body's internal systems, including the sexuality system, body temperature, and reactions to stress (Listiani, 2018). According to Karo-Karo (2017), childbirth mothers who were given aromatherapy had less labor pain intensity than those who were not given aromatherapy.

The Conservatory of Music Universitas Pelita Harapan Jakarta has shown the public that 2015 has opened up music therapy as a systematic intervention with therapists helping clients to improve their health using music experiences and the relationships that develop between them as dynamic forces of change. Music is an organized auditory stimulus consisting of melody, rhythm, harmony, timbre, form and style (Aizid, 2011). When music is applied in therapy, it can improve, restore and maintain the physical, mental, emotional, social and spiritual health of each individual. Music can relieve stress after playing at least 20-30 minutes of soothing music. A study conducted by Liviana (2017) showed that music therapy effectively reduced labor pain in the latent phase of the I stage of labor with as many as 30 respondents. Classical music has been shown to reduce labor pain in the active phase of the first stage in nulliparas (Oktavia, 2013).

Meta-analysis is a research method that combines similar research results (Murti, 2018). It is believed that this research method will obtain more accurate results because it combines the results of research that have been proven previously, then processed again to re-prove the truth. The truth of empirical research about a phenomenon will be stronger if the findings can be repeated in different populations, 
places, and times (Murti, 2018). In the meta-analysis method, research findings replace units or commonly called samples in an analysis.

Based on several research results found stating that aromatherapy and music therapy affect reducing labor pain. To determine the effectiveness of aromatherapy and music therapy, researchers were interested in studying more deeply in a systematic review using the meta-analysis method to produce more representative conclusions and become one of the references that can be used as considerations for reducing labor pain in the first stage.

\section{SUBJECTS AND METHOD}

\section{Study Design}

This systematic review and meta-analysis. Meta-analysis is an epidemiological study that combines and statistically combines the results of a number of independent primary studies that test the same hypothesis, in the same way to obtain a quantitative overview. Thus, a meta-analysis combines data in-directly, carries out epidemiological ex-plorations, and evaluates the results, so-called "epidemiology of results". And in the meta-analysis, research findings replace the individual as a unit (Murti, 2018).

Data were searched from the electronic database such as ProQuest, Science Direct, Google Scholar, and Springer Link. The keywords used in searching the articles were "labor pain", "music therapy", "aromatherapy", "reducing labor pain". The search results for articles were then collected in the Mendeley program to make it easier to write literature. This study used data collection steps according to the rules of writing a systematic review and metaanalysis, namely the PRISMA (Preferred
Reporting Item for Systematic reviews and Meta-analysis) method.

\section{Inclusion Criteria}

The inclusion criteria in this study were full-text articles using an English-language RCT study design over 10 years. The subjects used were primigravida and multigravida birth mothers.

\section{Exclusion Criteria}

The exclusion criteria for this study were articles with studies that did not use an RCT study design.

\section{Operational Definition of Variables} This study used PICO in formulating research problems. Population $=$ mothers giving birth, Intervention= giving aromatherapy and music therapy, Comparation= not being given aromatherapy and music therapy, Outcome $=$ reduction in labor pain.

Aromatherapy is a way of treating the body and healing diseases using essential oils.

Music therapy is a therapeutic activity that uses music as a medium to improve, maintain, and develop physical, mental, and emotional health.

Labor pain is an unpleasant feeling of individual response that accompanies the labor process due to physiological changes in the birth canal and uterus.

\section{Instruments}

The instrument for this research was the published articles that analyze the effectiveness of aromatherapy and music therapy in reducing labor pain in first-stage parturition mothers. Data processing consists of identifying articles from reputable journals, followed by a screening process for articles that met the terms and conditions of the researcher, which then passed for analysis using the Rev-Man 5.3 meta-analysis software.

\section{Data Analysis}

In this study, the data will be processed using Rev-Man 5.3. This analysis phase 
consists of two distinct parts. The first dealed with information related to the characteristics that described the primary study. The second dealt with the correct analysis of the synthesis results. The main analysis of the meta-analysis was a description of the magnitude of the effect obtained. Large-effect analyzes are integrated, combined, and compared usually in three sets. First, a single joint estimate of the effect size is usually the inverse of the variance estimate: as this variance is an inverse function of the effect size. Second, to study and test for homogeneity, this test determines whether fixed effects or random effects better analyze the statistics. The third is controlling for heterogeneity. Results can be seen in the forest plot.

\section{RESULTS}

Research related to the effectiveness of aromatherapy and music therapy on reducing labor pain in childbirth in the first stage consisted of 18 articles from 3 continents, namely the Asian continent, the European continent, and the American continent. Articles from the Asian continent come from Iran, Egypt, Thailand, Indonesia and Turkey. Articles from the Americas came from the United States, and articles from Europe came from Spain.

The initial search process yielded 365 articles, after deleting duplicated articles, 105 articles were found, 22 of which were eligible for a full-text review. Full articles included in the exclusion criteria because they did not use a Randomized Controlled Trial (RCT) study. The articles that met the qualitative requirements were reviewed again. Only 18 articles that met the qualitative requirements were divided into 2 categories according to the independent variables, namely aromatherapy and music therapy. The article review process can be seen in the search flow as follows.

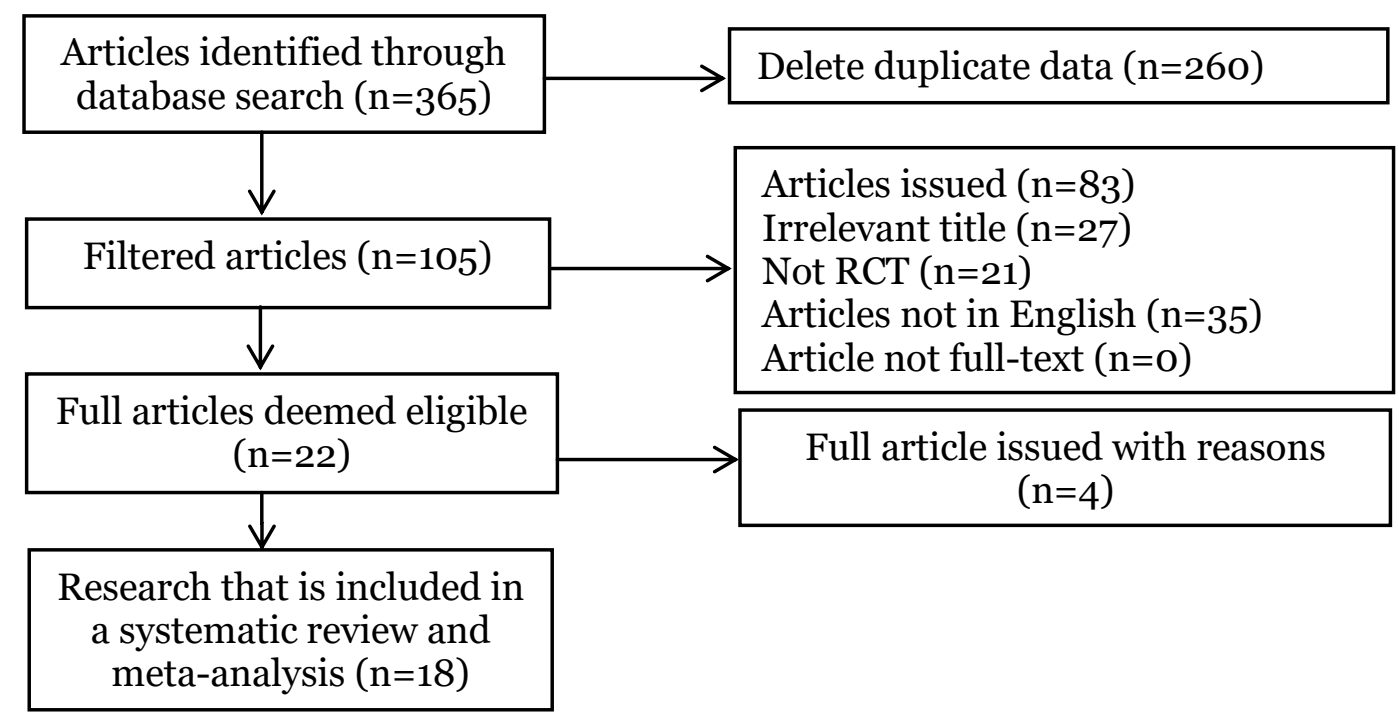

Figure 1. Flowchart of the review process

\section{Forest Plot (Aromatherapy)}

The interpretation of the results of the aromatherapy meta-analysis process can be seen through the forest plot. Figure 2 showed that the results of the analysis of the Randomized Controlled Trial (RCT) study of aromatherapy reduced the first stage of labor pain and was statistically significant $(\mathrm{p}<0.001)$. The data heterogeneity showed $\mathrm{I}^{2}=95 \%$, so that the Random 
Hasanah et al./ Aromatherapy and Music Therapy to Reduce Pain during Birth Delivery

Effect Model (REM) was used. Mothers giving birth in the first stage who received aromatherapy experienced a pain level of 0.85 units lower than those who did not receive aromatherapy $(\mathrm{SMD}=-0.85 ; 95 \%$ $\mathrm{CI}=-1.40$ to -0.31$)$.

\section{Funnel Plot (Aromatherapy)}

Figure 3 showed the plots on the right and left sides were not symmetrical with each other. Thus, they did not form an inverted funnel, indicating publication bias that reduced the actual effect (underestimate).

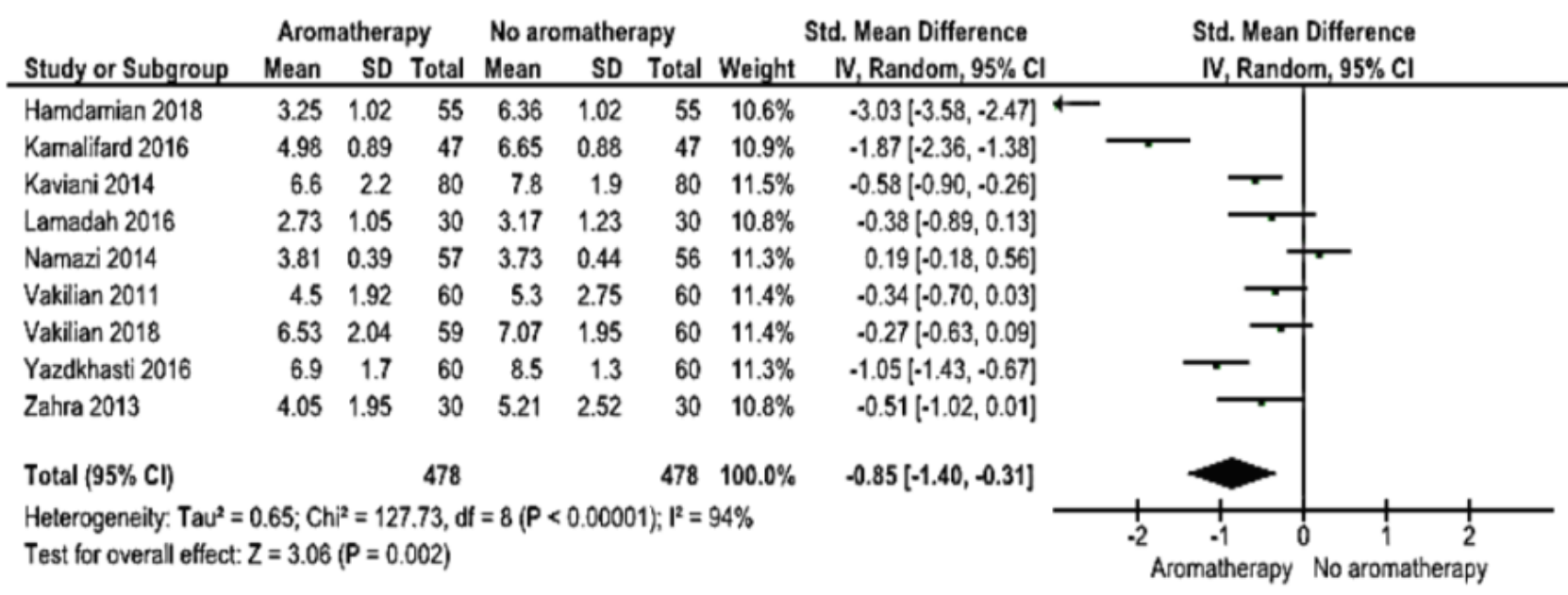

Figure 2. Forest plot of aromatherapy effectiveness to decrease labor pain in the first stage

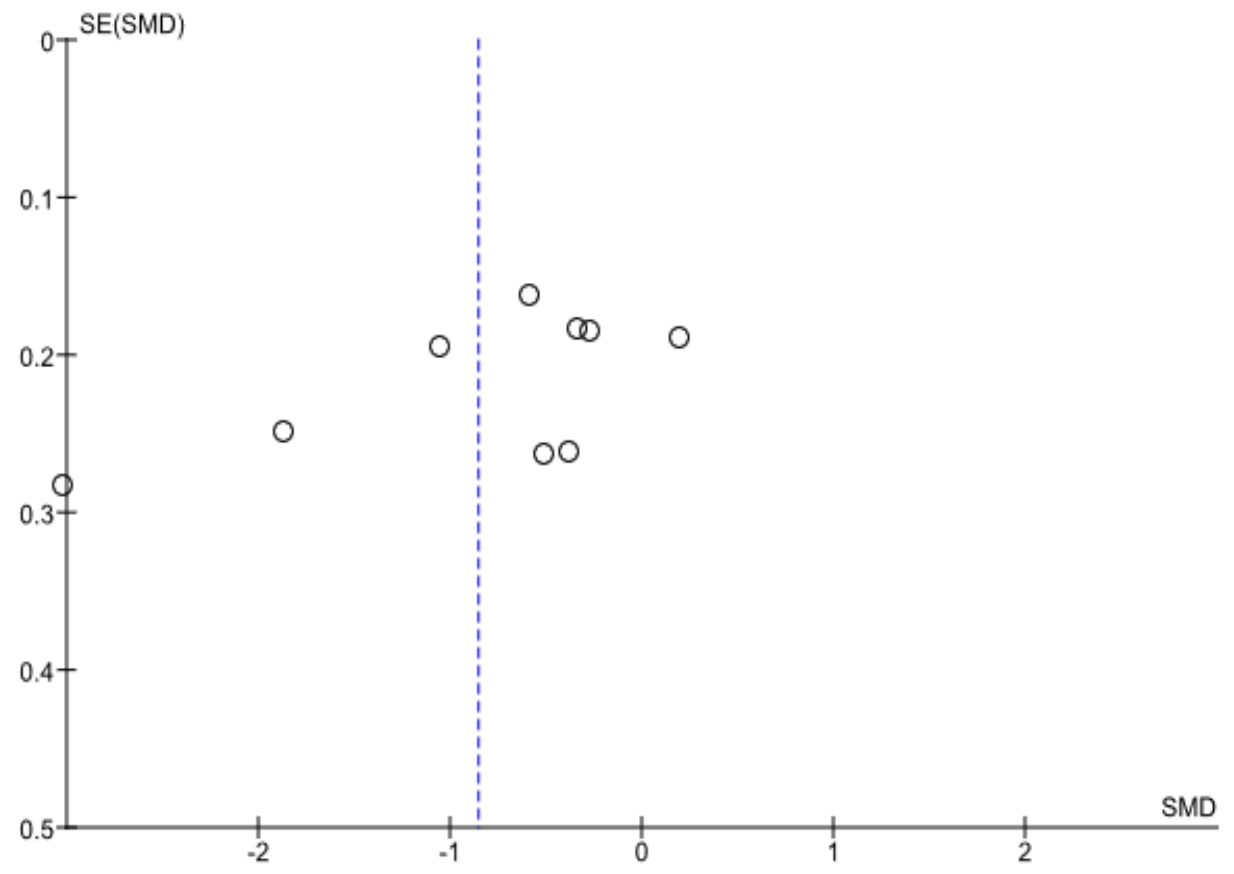

Figure 3. Funnel plot of aromatherapy effectiveness to reduce labor pain in the first stage 
Hasanah et al./ Aromatherapy and Music Therapy to Reduce Pain during Birth Delivery

\section{Forest Plot (Music therapy)}

The interpretation of the results of the music therapy meta-analysis process can be seen in the forest plot. Figure 4 showed that the results of the analysis of the Randomized Controlled Trial (RCT) study of music therapy reduced pain in the first stage of labor and was statistically significant $(\mathrm{p}<0.001)$. The heterogeneity of the research data showed $\mathrm{I}^{2}=95 \%$ so that the Random Effect Model (REM) was used.
First stage inpartum mothers who received music therapy experienced a pain level of 1.14 units lower than those who did not receive music therapy $(\mathrm{SMD}=-1.14 ; 95 \%$ $\mathrm{CI}=-2.18$ to -0.09$)$.

\section{Forest Plot (Music therapy)}

Based on Figure 5, the results between the right plot and the left plot are symmetrical, indicating a publication bias that reduces the actual effect (underestimate).

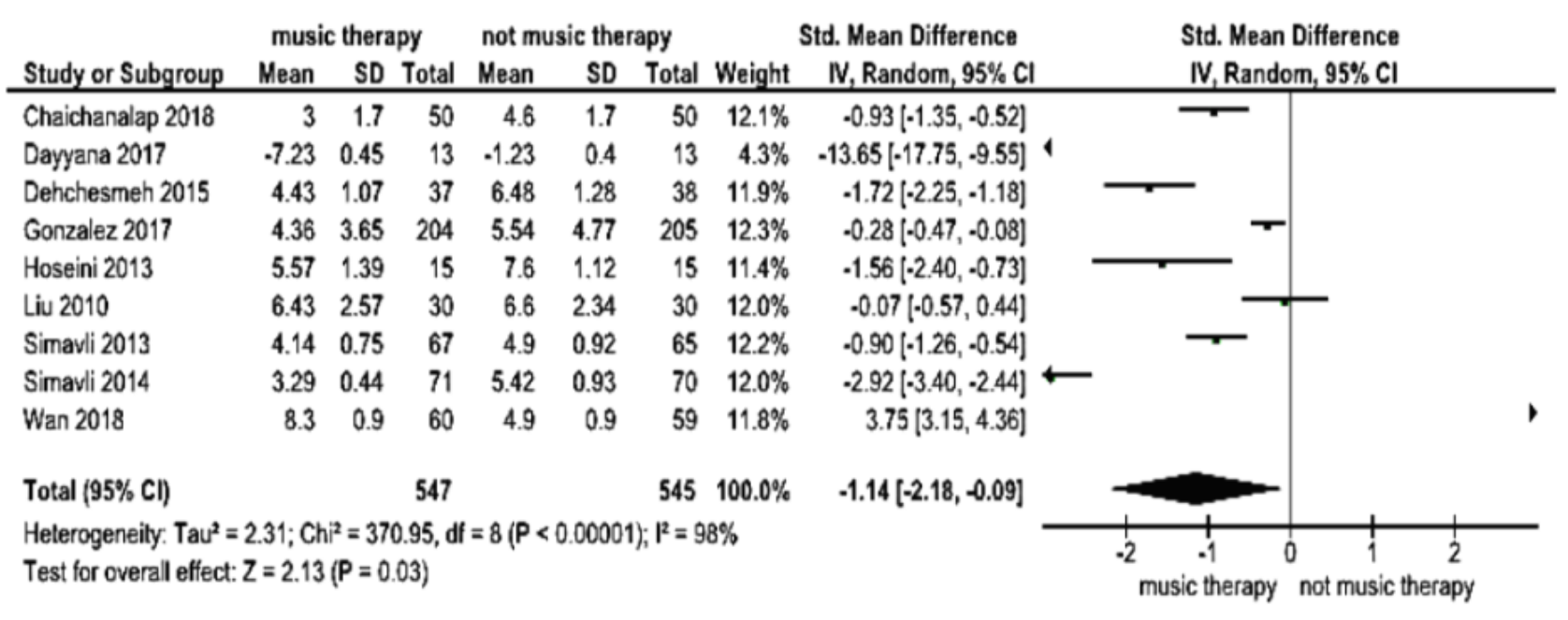

Figure 4. Forest plot of the effectiveness of music therapy on reducing pain in the first stage of labor

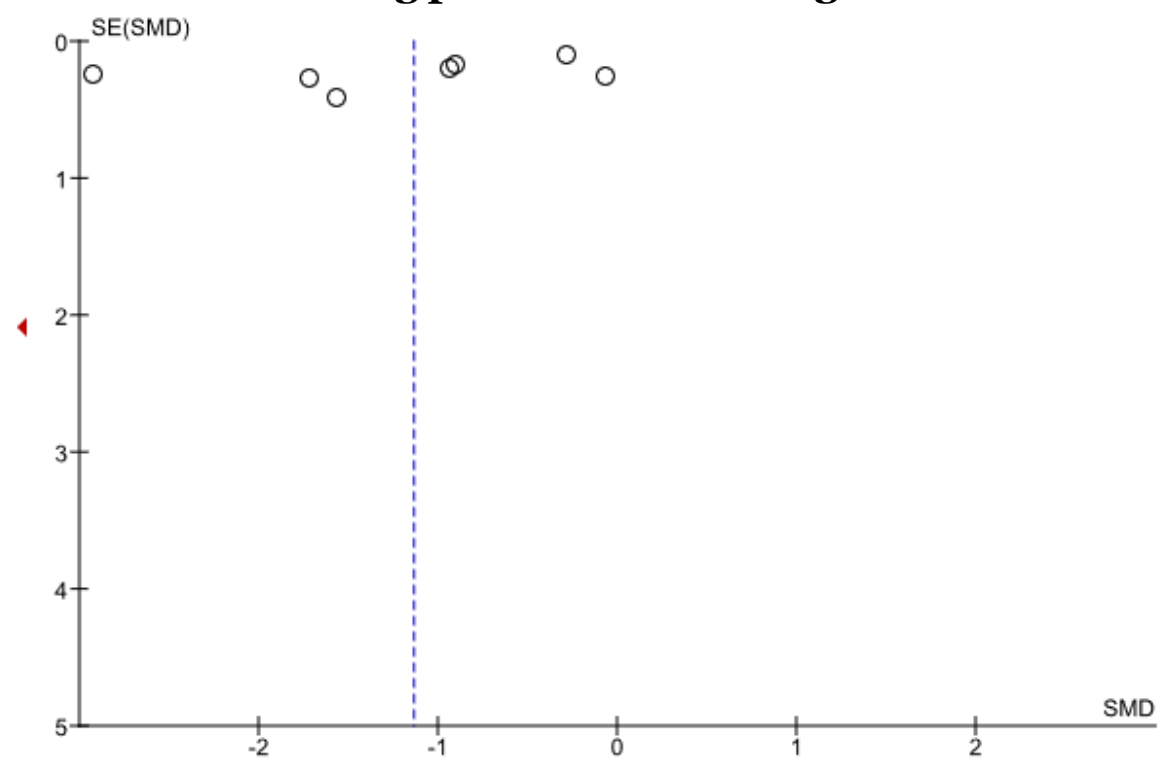

Figure 5. Funnel plot of music therapy effectiveness to decrease labor pain in the first stage 


\section{Labor Pain}

Labor pain is an unpleasant feeling due to the stimulation of special nerve endings. During labor and vaginal delivery, pain is caused by uterine contractions, cervical dilatation, and perineal distension. Visceral efferent nerve fibres that carry sensory impulses from the uterus enter the spinal cord in the 10th, 11th, and 12th thoracic segments and the first lumbar segment (T10 to L1) (Asmadi, 2012). Pain can be influenced by several factors, including socio-cultural, pain perception, previous pain experience, gender, and the placebo effect. The feeling of pain experienced by primiparas will be more pronounced at the beginning of labor. In multiparas, the pain will increase when labor has advanced, namely when the fetus declines, taking place rapidly in the second stage.

Labor pain can cause a sense of stress that causes the release of excessive hormones such as catecholamines and steroids. This hormone can cause smooth muscle tension and vasoconstriction of blood vessels. This can lead to decreased uterine contractions, decreased uteroplacental circulation, reduced blood and oxygen flow to the uterus, and causes uterine ischemia, increasing pain impulses. Kurniarum (2016) stated that labor pain could increase catecholamines by 20-60\%. This can cause activities in the uterus to become uncoordinated and result in prolonged labor.

Management of labor pain can be done non-pharmacologically, especially the provision of aromatherapy and music therapy. From the various studies obtained, no articles stated that the management of labor pain by giving aromatherapy or music therapy had an adverse effect that endangers the mother and the fetus. In Liviana's research (2017), it was found that the essential aroma in aromatherapy can reduce anxiety and depression so that it affects the production of endorphins which help mothers feel relaxed which can affect the smooth delivery process. Gonzalez (2017) stated that musical stimulation given to mothers in labor provided many advantages, including reducing the length of time in labor, reducing the number of cesarean sections, reducing forceps handling, and reducing episiotomy. This is because music therapy affects the mother's psychology in labor. Thus invasive management of the mother in labor is no longer needed.

\section{Aromatherapy}

Aromatherapy came from the word aroma, which means fragrant, and therapy, which can be interpreted as treatment or healing. So that aromatherapy can be interpreted as a way of treating the body and healing diseases using essential oils (Jaelani, 2017). The way aromatherapy works are through the body's circulatory system and sense of smell. Odour is a volatile molecule when it enters the nasal cavity through breathing, both in the bronchi and in the fine branches, and gas exchange occurs in the alveoli (Listiani, 2018). The olfactory nerves originate from receptors for olfactory neurons located in the olfactory mucosa. The olfactory nerves penetrate through the cribriform foramina in the ethmoidal bone to the olfactory bulb. Then the neurons in the olfactory bulb continue to the olfactory tract. And the neurons finally arrive at the olfactory cortex.

Listiani (2018) explained that the brain regulates and controls emotions and other human behaviors called the limbic system. The limbic system is a large part of the cortex on the medial side of the brain. The limbic system combines the limbic lobes and subcortical nuclei, namely the amygdala, septal nuclei, hypothalamus, epithelium, thalamic nucleus, and basal ganglia. All have a unitary relationship with 
each other and have a close relationship with the olfactory system. The amygdala is a complex of many small nuclei located below the cerebral cortex of the anterior medial pole of the temporal lobe. The amygdala has many two-way connections with the hypothalamus. One of the olfactoral regions ending in the amygdala is the corticomedial nucleus located just below the cerebral cortex in the piriformis area of the olfactory temporal lobe. The amygdala is an area of conscious behavior that works at the subconscious level. It functions to project on the limbic pathway of a person's system concerning the surrounding system and the mind. The amygdala is believed to play a role in processing and remembering emotional reactions. The olfactory nerve receptors will receive olfactory stimuli to the olfactory bulb, directly to the piriformis cortex. The piriform cortex will project directly to the amygdala. The amygdala transmits signals to the hypothalamus. The hypothalamus is very important to help the brain in storing new memories. The hypothalamus sends nerve impulses to the nuclei in the brainstem that control the function of the autonomic nervous system, which reacts directly on smooth muscles and internal organs, resulting in several bodily changes such as an increase in heart rate and blood pressure.

Janula and Marhipal (2015) said that aromatherapy could reduce labor pain because of the sedative effect of linalool acetate contained in aromatherapy as a narcotic. The type of aromatherapy that can be used and provides the most sedative effect in reducing labor pain is lavender aromatherapy because of the linalool acetate content. Research conducted by Lamadah (2015) showed that an effective way of giving aromatherapy is through massage in which essential oils are applied to the patient's body, and pain reduction will be felt within five minutes of giving the massage. Another study conducted by Zahra (2013) confirmed that aromatherapy massage is the most effective way to reduce labor pain in the first stage.

\section{Music Therapy}

Music therapy is a systematic intervention process by which the therapist helps clients improve their health using music experiences and the relationships between them as dynamic forces of change (Bruscia, 2014). After listening to music, sound impulses are received by the earlobe of the reader and start the hearing process. Physiologically, hearing is the ear receiving sound waves, distinguishing frequencies and sending information to the central nervous system, which will be carried to the thalamus and received by the amygdala in the limbic system. After that, the thalamus sends signals to the neocortex, while the amygdala sends signals to the hypothalamus. The hypothalamus is very important to help the brain in storing new memories. The hypothalamus transmits nerve impulses to the nuclei in the brainstem that control the function of the autonomic nervous system, which reacts directly on smooth muscles and internal organs, resulting in several body changes such as an increase in heart rate and blood pressure (Primadita, 2011).

In a study conducted by Celebi (2020), music played during the patient's treatment process can reduce the respiratory rate, heart rate, and systolic and diastolic blood pressure. Simavli (2013) explained that soft instrumental music given in the first 3 hours of the active phase has beneficial effects in the labor process, including reducing anxiety and pain felt by the mother during labor, reducing the need for analgesics after childbirth, and increaseing basal FHR. Chaichanalap (2018) stated 
that giving ibuprofen and acetaminophen with codeine can reduce pain. Still, there are side effects, but music therapy is believed to have no side effects and does not cause discomfort to patients as in giving cold compresses. In his research, he explained that music therapy could reduce pain during the labor process both in the first stage and 6 hours after the baby is born because music can distract the pain.

\section{The effectiveness of aromatherapy on reducing labor pain}

Based on the interpretation of the results of the analysis of 9 articles through the forest plot (Figure 2) regarding the effectiveness of aromatherapy on reducing labor pain in the first stage, it was found that aromatherapy reduced labor pain. Based on the analysis results, there is a high heterogeneity indicated by the value of $\mathrm{I}^{2}=95 \%$, so that the Random Effect Model (REM) is used. First stage inpartum mothers who received aromatherapy experienced a pain level of 0.85 units lower than those who did not receive aromatherapy $(\mathrm{SMD}=-0.85$; 95\% CI $=-1.40$ to -0.31 ). In Figure 3 , the funnel plot of the effectiveness of aromatherapy on reducing labor pain in the first stage shows that the right and left sides are not symmetrical to each other and do not form an inverted funnel, the left plot has a standard error of $>0.1$ to $<0.3$ and the right plot has a standard error of $>0.1$ to $<0.3$, which indicates that there is publication bias.

Research conducted by Lamadah (2016) explains that aromatherapy is a nonpharmacological method to relieve pain as a mild sedative and antispasmodic. The effectiveness of essential oils in reducing labor pain is due to the sedative effect of linalool acetate in essential oils as a narcotic, which is useful for normalizing emotional states and unbalanced body conditions and being a sedative tonic, especially in the nervous system. Kaviani (2014) explained that aromatherapy has a relaxing effect on reducing labor pain in primiparas and multiparas. In Tarsikah's research (2012), essential oils, such as lavender, contain 8\% terpenes and 6\% ketones used as sedatives. In addition, the aroma produced by aromatherapy will stimulate the thalamus to se-crete encephalins, which function as natural pain relievers.

Turlina (2017) stated that there is a decrease in the scale of labor pain in labor in the first stage after being given aromatherapy and is also supported by research by Stea S (2014), which showed that essential oil therapy has a positive effect on anxiety and insomnia which can be used to treat anxiety and insomnia and to reduce pain. The aroma that comes from aromatherapy works to affect emotions in inpartum mothers with the limbic system and the brain's emotional center. The smell that comes from aromatherapy is received by receptors in the nose and then sent to the spinal cord in the brain. These alpha waves in the brain help a person to feel relaxed.

\section{The effectiveness of music therapy on reducing labor pain}

The interpretation of the analysis of 9 articles through the forest plot of the effectiveness of music therapy on reducing labor pain in the first stage (Figure 4) showed that music therapy reduces labor pain in the first stage (BRAKE). First stage inpartum mothers who received music therapy experienced a pain level of 1.14 units lower than those who did not receive music therapy $(\mathrm{SMD}=-1.14 ; 95 \% \mathrm{CI}=-2.18$ to -0.09). The analysis results through the funnel plot of the effectiveness of music therapy on reducing labor pain in the first stage (Figure 5) showed that the right and left plots were symmetrical. The left plot 
has a standard error of $>0$ to $<1$, and the right plot has a standard error of $>0$ to $<1$, which indicated no publication bias. Oktavia (2013) explained that music therapy could stimulate endorphins which have a relaxing effect on the body and function to inhibit the transmission of electrical impulses from one neuron to another by neurotransmitters in the synapse. These substances can cause analgesic effects that can ultimately eliminate pain neurotransmitters in the brain's somatic sensory perception and interpretation center. So in this process can result in reduced pain. Music that is listened to intensively can reflect emotions in the body, enlightenment of the soul, and expression. Music can slow down and speed up electrical waves in the brain to change the work of body systems (heart rate and blood pressure).

Moekroni (2016) explained that music could provide energy and command through rhythm so that music with the right tempo and the mother's choice can reduce anxiety and pain during labor.

Study by Suryani (2016) in accordance with this study that music therapy influenced reducing the intensity of pain behavior in the first stage of labor, where 10 research subjects were given complementary therapy to music therapy stated that labor pain felt lighter than before being given music therapy. This study stated that music therapy can reduce levels of tension and emotional or physical pain.

This study was also supported by Chaichanalap (2018) that music therapy can reduce various complex pains during the labor process consisting of perineal pain, pain due to uterine contractions, and fatigue. Giving music therapy has a greater effect on reducing labor pain than giving interventions according to pain management procedures.

\section{AUTHOR CONTRIBUTION}

Uswatun Hasanah was the main researcher who chooses the topic, searches for the data in this study. Bhisma Murti and Hanung Prasetya conducted data analysis and reviewed research documents.

\section{FUNDING AND SPONSORSHIP}

This study was self-funded.

\section{CONFLICT OF INTEREST}

There was no conflict of interest in this study.

\section{ACKNOWLEDGMENT}

The author would like to thank all those who have helped prepare this article and the database providers ProQuest, Science Direct, Google Scholar, and Springer Link.

\section{REFERENCES}

Aizid R (2011). Sehat dan cerdas dengan terapi musik (Healthy and smart with music therapy). Yogyakarta: Laksana.

Asmadi (2012). Teknik Prosedural Keperawatan: Konsep dan aplikasi kebutuhan dasar klien (Nursing Procedural Techniques: Concept and application of client's basic needs). Jakarta; Nuha Medika.

Black J, Hawks J (2014). Keperawatan Medikal Bedah: Manajemem Klinis untuk Hasil yang Diharapkan (Medical Surgical Nursing: Clinical Management for Expected Outcomes). Dialih bahasakan oleb Nampira R. Jakarta: Salemba Emban Patria.

Bruscia KE (2014). Defining Music Therapy (rd Ed). Gilsum, NH: Barcelona Publishers.

Çelebi D, Yılmaz E, Şahin ST, Baydur H (2020). The effect of music therapy during colonoscopy on pain, anxiety and patient comfort: A randomized controlled trial. Complement Ther 
Clin Prac. 38: 101084. https://doi.org/10.1016/j.ctcp.2019.10108.

Chaichanalap R, Laosooksathit W, Kongsomboon $\mathrm{K}$, Hanprasertpong $\mathrm{T}$ (2018). Efficacy of music therapy on immediate postpartum episiotomy pain: a randomized controlled trial. Thai J Obstet Gynaecol. 26(3): 158165. heo2.tci-thaijo.org

García González J, Ventura Miranda MI, Requena Mullor M, Parron Carreño T, Alarcón Rodriguez R (2018). Effects of prenatal music stimulation on state/trait anxiety in full-term pregnancy and its influence on childbirth: a randomized controlled trial. Journal of Maternal-Fetal and Neonatal Medicine, 31(8), 1058-1065. https://doi.org/10.1080/14767058.2017.1306 511

Jaelani (2017). Aroma therapy. Jakarta: Pustaka Populer Obor.

Janula R, Mahipal S (2015). Effectiveness of aromatherapy and biofeedback in promotion of labour outcome during childbirth among primigravidas. Health Science Journal, 9(1), 1-5. http://journals.imedpub.com/

Karo Karo, HY Pramono, Wahyuni S, Mashoedi ID, Latifah L (2017). Lavender (Lavandula Angustifolia) aromatherapy as an alternative treatment in reducing pain in primiparous mothers in the active first stage of labor. Belitung Nurs J. 3(4): 420-425. https://doi.org/10.33546/bnj.159

Liviana, Handayani TN, Mubin MF, Itibsyaroh I, Ruhimat A (2017). Efektifitas terapi musik pada nyeri persalinan kala i fase laten (The effectiveness of music therapy on labor pain in the latent phase I). J Ners Widya Husada; 4(2):47-52. stikeswh.ac.id

Kurniarum A (2016). Asuhan kebidanan persalinan dan bayi baru lahir
(Maternity and newborn midwifery care). Jakarta Selatan; Pusdik SDM Kesehatan.

Mansour Lamadah S (2016). The effect of aromatherapy massage using lavender oil on the level of pain and anxiety during labour among primigravida women. Am J Nurs Sci. 5(2): 37. https://doi.org/10.11648/j.ajns.20160 502.11

Murti B, (2018). Prinsip dan metode riset epidemiologi (Epidemiological research principles and methods). Karanganyar: Bintang Fajar Offset.

Oktavia NS, Gandamiharja S, Akbar IB (2013). Perbandingan efek musik klasik mozart dan musik tradisional gamelan Jawa terhadap pengurangan nyeri persalinan kala I fase aktif pada nulipara (Comparison of the effects of mozart's classical music and traditional Javanese gamelan music on reduction of labor pain in the first stage of active phase in nulliparas). Maj Kedokteran Bandung. 45(4): 218225. doi:10.15395/mkb.v45n4.174.

Saifuddin (2013). Buku acuan nasional pelayanan kesehatan maternal dan neonatal (National reference book for maternal and neonatal health services). Jakarta: Yayasan Bina Pustaka Sarwono Prawirohardjo.

Simavli S, Kaygusuz I, Gumus I, Usluogullari B, Yildirim M, Kafali H (2014). Effect of music therapy during vaginal delivery on postpartum pain relief and mental health. J Affective Dis. 156: 194-199. https://doi.org/10.1016/j.jad.2013.12.027.

Stea S, Beraudi A, De Pasquale D (2014). Essential oils for complementary treatment of surgical patients: State of the art. Evid-Based Complementary Altern Med. 2014 :726341. https://doi.org/10.1155/2014/726341. 
Suryani E, Yulaikah S (2016). Efektifitas penerapan lingkungan persalinan dengan terapi komplementer (Aromaterapy, terapi musik dan terapi relaksasi) terhadap penurunan intensitas nyeri persalinan kala I fase aktif (The effectiveness of the application of the labor environment with complementary therapy (Aro-matherapy, music therapy and relaxation therapy) on reducing the intensity of labor pain in the first stage of active phase). J Kebidanan dan Kesehat Tradis. 1(1): 55-63. doi:10.37341/jkkt.vii1.64.

Tarsikah Susanto H, Sastramihardja HS (2012). Penurunan nyeri persalinan primigravida kala I fase aktif pascapenghirupan aromaterapi lavender (Reduction of primigravida labor pain stage I active phase post inhalation lavender aromatherapy). Majalah Kedokteran Bandung, 44(1): 19-26. https://doi.org/10.15395/mkb.v44n1.210 .

Turlina L (2017). Pendidikan Ibu Pekerjaan Ibu (Mother's Education Mother's Work). Surya, 09(01).

Yanti (2010). Buku ajar kebidanan persalinan (Midwifery textbook). Yogyakarta: Pustaka Rihama

Zahra A (2013). Lavender aromatherapy massag-es in reducing labor pain and duration of labor: A randomized controlled trial. African Journal of Pharmacy and Pharmacology, 7(8), 456430. https://doi.org/-10.5897/ajpp-12.391 